\title{
A COMPARISON OF THICK SMEARS, QBC MALARIA, PCR AND PATH Falciparum MALARIA ${ }^{\circledR}$ Test TRIP IN PLASMODIUM FALCIPARUM DIAGNOSIS
}

\author{
GAYE O.*, DIOUF M.* \& DIALLO S.*
}

\begin{abstract}
Summary :
Blood samples from 182 patients presenting at the out-patient clinic in Richard-Toll, Senegal were analysed by Thick smear microscopy, the QBC, PCR and the new dipstick PATH Malaria ${ }^{\circledR}$ assay which detects the histidine rich protein II antigen of Plasmodium falciparum. Thick smear microscopy was used as the reference method.

Sensitivity, specificity, predictive positive and negative values were $100 \%, 83.6 \%, 93.4 \%$ and $100 \%$ for QBC respectively; $100 \%, 72.7 \%, 89.4 \%$ and $100 \%$ for PCR; $96 \%, 92.7 \%$, $96.8 \%$ and $91 \%$ for the PATH assay. PATH assay failed to detect one positive sample with Plasmodium malariae. Assays were also compared with regard to the expense of equipment and reagents and speed and ease of use. The rapid PATH assay can be performed with minimal training and may be specially useful in areas where $P$. falciparum is the predominant malaria species, in epidemic malaria regions, and where skilled microscopy is not readily available.
\end{abstract}

KEY WORDS : thick smear, QBC, PCR, PATH falciparum malaria ${ }^{\circledR}$ assay, Histidine Rich Protein 2, Plasmodium falciparum, malaria, Senegal.

T The worsening problems of antimalarial drugs resistance in many settings has led to facilitate early diagnosis and prompt treatment. Microscopic examination of blood smears remains the method of choice for diagnosing malaria. Newer technologies that have been evaluated include the polymerase chain reaction PCR (Barker et al., 1992; Mc Laughlin et al., 1987), the QBC malaria assay (Levine et al., 1989), assays detecting the Plasmodium falciparum histidinerich protein 2 (PfHRP-2), a water soluble protein released from parasitized erythrocytes (Howard et al., 1986; Parra et al., 1991). These related assays include the PATH falciparum malaria ${ }^{\circledR}$, a dipstick antigen capture assay developed by PATH (Seattle, USA).

The purpose of this study was to evaluate the performance and use of the PATH Falciparum Malaria ${ }^{\circledR}$ Test Trip for the diagnosis of Plasmodium falciparum malaria compared to three other $P$. falciparum diagnostic assays, Thick smear microscopy, QBC and PCR.

\footnotetext{
* Department of Parasitology, Faculty of Medicine, UCAD, Dakar, Sénégal.

Correspondence: Oumar Gaye.

Tel. (221) 8251998 - Fax (221) 8252952.

E-mail: ogaye@ucad.refer.sn
}

Résumé : Étude COMPARATIVE DE LA GOUTTE ÉPAISSE, DU QBC, DE LA PCR ET DU PATH Falciparum Malaria ${ }^{\circledR}$ Test Trip POUR LE DIAGNOSTIC DU PALUDISME

182 prélèvements de sang effectués chez des malades vus en consultation au centre de santé de Richard-Toll au Sénégal ont été analysés par la goutte épaisse, le QBC, la PCR et le PATH Falciparum Malaria ${ }^{\circledR}$ Test Trip, ce dernier détectant la protéine Histidine II de Plasmodium falciparum. La goutte épaisse est prise comme méthode de référence.

La sensibilité, la spécificité, les valeurs prédictives positive et négative étaient respectivement de $100 \%, 83,6 \%, 93,4 \%$ et $100 \%$ pour le QBC; $100 \%, 72,7 \%, 89,4 \%$ et $100 \%$ pour la PCR; $96 \%, 92,7 \%, 96,8 \%$ et $91 \%$ pour le PATH. Ce dernier n'a pas diagnostiqué l'infection due à Plasmodium malariae. Les tests ont été comparés également selon les équipements et matériels utilisés, leur rapidité et la facilité de réalisation. Le PATH peut être réalisé après une rapide formation et peut être utile dans les zones où $\mathrm{P}$. falciparum est l'espèce dominante, et où un examen microscopique de qualité n'est pas possible.

MOTS CLÉS : goutte épaisse, QBC, PATH falciparum malaria ${ }^{\circledR}$, Histidine Rich Protein 2, Plasmodium falciparum, paludisme, Sénégal.

\section{MATERIALS AND METHODS}

\section{PATIENTS}

Trom November 1997 to January 1998, 182 patients 4 with malaria symptoms presenting at the out 1 patient clinic in Richard-Toll, in the north of Senegal, were enrolled in the study. The age distribution was $1-55$ years.

Thick blood examinations were made using blood from a digital puncture. For PCR, PATH assay and QBC, additional blood $(5 \mathrm{ml})$ was collected by venipuncture into $10 \mathrm{ml}$ heparinized tubes.

\section{MiCROSCOPY}

Thick smears were lysed in water and were stained with Giemsa. Numbers of malaria parasites per 1,000 white cells were counted and the average parasitemias were calculated assuming 8,000 white cells per microliter of blood. For the QBC malaria analysis, blood was collected in acridine orange-coated microhematocrit tubes (Becton Dickinson), centrifuged in a microhematocrit centrifuge, examined using a $60 \mathrm{x}$ oil immersion objective, and samples were scored as positive or negative. 


\section{Polymerase Chain Reaction: PCR}

DNA was isolated from $100 \mu \mathrm{l}$ of blood by phenol extraction and isopropanol precipitation (Isoquick method), then dissolved in $100 \mu \mathrm{l}$ of $0.1 \mathrm{TE}$ solution, then diluted in water $1 / 10$. Amplification was performed using $3 \mu \mathrm{l}$ of diluated DNA in $30 \mu \mathrm{l}$ reaction volumes, using Perkin Elmer PCR kit with $2.5 \mathrm{mM}$ magnesium and a pair of specific primers from the small subunit ribosomal DNA gene. After an initial heating step for two minutes at $94^{\circ}, 15$ thermal cycles with one minute denaturation at $94^{\circ}$, one minute annealing at $58^{\circ}$ and one minute extension at $72^{\circ}$ followed by 22 additional thermal cycles with $54^{\circ}$ hybridization. Amplification products were resolved using $2 \%$ agarose gels and visualised and photographed after staining in ethidium bromide (Barker et al., 1992).

\section{PATH FALCIPARUM MALARIA ${ }^{\circledR}$ ASSAY}

The test developed by the Program for Appropiate Technology in Health (Seattle, USA) is an antigen-capture assay which detects $P$. falciparum specific histidinerich protein II (PfHRP-II). The assay uses an IgG capture monoclonal antibody which is immobilized on the nitrocellulose menbrane. Once the test strips identified with patients numbers, four drops of sample buffer were added into each reaction tube and the tubes were placed in reaction stand. For each sample, $5 \mu$ l of whole blood were added onto the test strip, just below the blue arrows. Then the test strips were dropped into the reaction tube. After 10 minutes $1 \mathrm{ml}$ of clearing buffer was added. Then the test tube was capped, inverted several times. For negative samples only a line appears in the control region. For positive samples another line appeared at the strip's capture region.

\section{DATA ANALYSIS}

Sensitivity, specificity, positive and negative predictive values were calculated using microscopy as the standard method.

\section{RESULTS}

$T^{n}$ $\mathrm{n}$ this study 182 patients with clinical symptoms of malaria were examined using thick smear and QBC 1 microscopic analyses, the PCR and the new PATH Falciparum Malaria ${ }^{\circledR}$ assay. One hundred and twenty seven samples were detected as positive by examination of stained smears at relative parasitemia ranging from 500 to 186,286 parasites per microliter of blood. 126 were $P$. falciparum. One was $P$. malariae.

\section{QBC MALARIA ASSAY}

On the 182 samples analyzed by QBC, 127 were positive by both thick smear microscopy and QBC. Nine samples were positive by QBC and negative by microscopy, and these samples were also positive by PCR analysis. Relative to microscopy, sensitivity of QBC assay was $100 \%$, specificity was $83.6 \%$, the positive predictive value was $93.4 \%$ and the negative predictive value was $100 \%$ (Table I).

\begin{tabular}{lccc}
\hline & Microscopy $^{+}$ & Microscopy $^{-}$ & Total \\
\hline $\mathrm{QBC}^{+}$ & 127 & 9 & 136 \\
$\mathrm{QBC}^{-}$ & 0 & 46 & 46 \\
\hline Total & 127 & 55 & 182 \\
\hline
\end{tabular}

Table I. - Comparison of QBC to thick smear microscopy.

\section{PCR}

One hundred and twenty seven (127) samples were both positive by microscopy and by PCR. Fifteen were negative by microscopy but positive by $\mathrm{PCR}$ which detects six more positive samples than QBC.

Using thick smear microscopy as the standard method, the sensitivity of PCR was $100 \%$, the specificity $72.7 \%$, positive predictive value $89.4 \%$, negative predictive value $100 \%$ (Table II).

\begin{tabular}{lccr}
\hline & Microscopy $^{+}$ & Microscopy & Total \\
\hline PCR $^{+}$ & 127 & 15 & 142 \\
PCR $^{-}$ & 0 & 40 & 40 \\
\hline Total & 127 & 55 & 182 \\
\hline
\end{tabular}

Table II. - Comparison of PCR to thick smear microscopy.

\section{PATH ASSAY}

Each assay run was performed and scored within ten minutes. Strong positives were identified near the top of the Test Strip. A positive control dash was seen at the control region of all strips. The assay was easy to perform following the manufacturer's instructions, and requires no equipment. One hundred and twenty two samples were detected as positive by PATH assay. For the five missed samples, all positive by QBC and PCR, one had parasitemia at $500 \mathrm{p} / \mu \mathrm{l}$ blood, another one was $P$. malariae and the last three were samples which have been freezed and thawed repeatedly. Four samples positive by PATH assay were negative with PCR, QBC and microscopy using thick smear microscopy as the standard method. The sensitivity of PATH assay was $96 \%$, specificity was $92.7 \%$, the positive predictive value was $96.8 \%$ and the negative predictive value was $91 \%$ (Table III).

The intensities of the positive PATH reactions were generally correlated with the densities of parasitemias determined by thick smear microscopy. 


\begin{tabular}{lccc}
\hline & Microscopy $^{+}$ & Microscopy & Total \\
\hline PATH $^{+}$ & 122 & 4 & 126 \\
PATH $^{-}$ & 5 & 51 & 56 \\
\hline Total & 127 & 55 & 182 \\
\hline
\end{tabular}

Table III. - Comparison of PATH assay to thick smear microscopy.

\section{DISCUSSION}

A

battery of 182 blood samples from Senegal was analyzed with four different malaria diagnosis assays. This allowed comparisons between technologies and illustrates features to be considered when evaluating diagnostic assays.

The PCR results were repeated twice and consistently detected 15 additional positive samples compared to thick smear microscopy. It is plausible that, as reported, the PCR is a maximally sensitive assay, but false positive are also common problems with PCR (Barker $e t$ al., 1992). Three positive samples freezed and thawed repeatedly positive by microscopy were negative with PATH assay; although histidine II antigene is apparently stable, multiple freeze-thawed samples may decrease the sensitivity of the assay. The blood sample with $P$. malariae was scored negative. This confirms the antigen histidine-rich protein II is specific of $P$. falciparum (Howard et al., 1986; Parra et al., 1991)

The correlation between parasite densities by thick smear microscopy and signal intensity scores of the PATH assay suggests that this technique provided a semiquantitative estimation of parasitemias. Even though the detection limit was not determined during this study, we might consider PATH assay can detect at least $1000 \mathrm{p} / \mu \mathrm{l}$, a sample with $500 \mathrm{p} / \mu \mathrm{l}$ having been not detected.

Four samples scored positively by PATH assay were negative with the other assays. These patients reported having had malaria and having been treated. It is known that histidine II antigen may be detectable following drug treatment even when parasites are no longer visible in the blood by microscopy.

Transportation, speed, convenience, equipment, labor, and supply costs are often critical factors in malaria diagnosis. Thick smear microscopy when correctly done is inexpensive with regard to supply costs, and can detect as low as ten parasites per microliter of blood, but it requires a good microscope and a skilled technician. QBC and PCR can provide additional sensitivity, which may be useful when asymptomatic carrier detection is important, but equipment, labor and supply costs are relatively high.

The PATH assay does not require the initial equipment cost. The antigen detection is simple, rapid, suitable for use by relatively less-trained personnel and the rea- gents are relatively stable and portable. Its sensitivity is a little higher than ICT and Parasight. A previous study we carried out noted $89 \%$ and $86 \%$ respectively for ICT and Parasight (Gaye et al., 1998).

When malaria diagnosis is not readily available as in peripheral areas, and where epidemic outbreak is possible as in the case with hypoendemic and seasonal malaria, PATH assay may be specially useful (Gaye et al., 1989, 1991, 1997). However it is an indirect tool and final diagnosis should be made with correlation with clinical and epidemiological criterias. So far, depending the ratio cost and efficacy, microscopy examination remains the best tool for malaria diagnosis.

\section{ACKNOWLEDGEMENTS}

We thank $\mathrm{D}^{\mathrm{r}}$ D.Burgess, Program officer at PATH corporation for providing the kit's test.

\section{REFERENCES}

Barker R.H. Jr., Banchongaksorn T., Courval J.M., SuwonKeRD N., RimQungtragon K. \& WirTh D.F. A simple method to detect Plasmodium falciparum directly from blood samples using PCR. American Journal of Tropical Medecine and Hygiene, 1992, 41, 266-272.

Mc Laughlin G.L., Ruth J.L., Jablonski E., Steketee R. \& CampBELL G. Use of enzyme-linked synthetic DNA in diagnosis of P. falciparum malaria. Lancet, 1987, 1, 714-716.

Levine R.A., Wardiaw S.C., \& Patton C. Detection of hemoparasite using QBC analysis tubes. Parasitology Today, 1989, 5, 132-134.

Howard R.J., Uni S., Ailkawa M., Aley S.B., Wellems T.M., Rener J. \& TAYlor D.W. Excretion of a malarial histidine rich-protein(PfHRP II) from Plasmodium falciparum infected erythrocytes. Journal of Cell Biology, 1986, 103, 1269-1277.

PARRA M.E., Evans C.B. \& TAYlor D.W. Identification of Plasmodium falciparum histidine rich protein 2 in the plasma of humans with malaria. Journal of Clinical Microbiology, 1991, 29, 1629-1634.

Gaye O., Diouf M., Dansokho E.F., Mclaughlin G.L. \& Diallo S. Diagnosis of Plasmodium falciparum malaria using Parasight F, ICT malaria PF and Malaria IgG celisa assays. Parasite, 1998, 5, 189-192.

Gaye O., Bah I.B., Diallo S. \& Faye O. Morbidité palustre. Etude de 353 accès fébriles. Médecine Tropicale, 1989, 49, 401-404.

Gaye O., Bah I.B., Diallo S. \& Trape J.F. Évolution de la chloroquinorésistance de $P$. falciparum. Annales de la Société Belge de Médecine Tropicale, 1991, 71, 329-330.

GAYE O. Rapport d'évaluation du kit PATH Falciparum Malaria IC Strip Test. Doc. Parasitologie, 1997.

Reçu le 4 janvier 1999 Accepté le 18 juin 1999 